\title{
Thoracican cirripedes (Crustacea) from the Hauterivian (Lower Cretaceous) of Hannover, northern Germany
}

Andy Gale

School of Earth and Environmental Sciences, University of Portsmouth, Burnaby Building, Burnaby Road, Portsmouth PO1 3QL UK

andy.gale@port.ac.uk

Abstract. Diverse thoracican cirripedes from the Hauterivian of the Hannover district of northern Germany are described, including seven species, belonging to five genera. Of these, a new genus belonging to the Scalpellidae, Jaegerscalpellum, includes one Hauterivian species, J. elegans sp. nov., an Aptian species, J. comptum (Withers, 1910) and an Albian species, J. politum (Darwin, 1851) are also referred to it. A new Cretiscalpellum, C. mutterlosei sp. nov. is described from the Hauterivian, and C. matrioni sp. nov. is described from the Middle Albian of France. The oldest record of the Unilatera Gale, 2018, Pedupycnolepas pulcher sp. nov. is described from the Hauterivian; this displays typical shell structure of the group, retained by living Verrucidae. Finally, four species of Zeugmatolepadidae, subfamily Martillepadinae, are recorded from the Hauterivian, including Martillepas hausmanni (Koch and Dunker, 1836), M. decoratus sp. nov., M. auriculum sp. nov. and Etcheslaepas borealis (Collins, 1990). The Hauterivian fauna from Hannover shows affinities both with Late Jurassic and later Cretaceous (Aptian-Cenomanian) forms, and includes the earliest scalpellids, unilateran (Pedupycnolepas) and Cretiscalpellum species known. It constrains the age of the Cretaceous cirripede evolutionary radiation to the earliest Cretaceous.

Key words. Cirripedes, Lower Cretaceous, Germany 


\section{Introduction.}

The earlier part of the Lower Cretaceous (Berriasian-Barremian) has yielded very few cirripedes, which presents palaeontologists with a dilemma, because the interval was a critical period in their evolutionary history (Gale 2018). In the Lower Aptian, the living family Scalpellidae appeared quite suddenly (Withers 1935, 1946), represented by the genera Arcoscalpellum and Virgiscalpellum, and in the Upper Aptian, the typical later Cretaceous genus Cretiscalpellum first occurred. Cirripede valves are common fossils in the Albian Gault Clay of the Anglo-Paris Basin, which has yielded about fourteen species (Collins1974). Late Jurassic cirripedes are now quite well known, thanks largely to the collecting of Steve Etches in the Kimmeridge Clay of Dorset (Gale 2014a, 2018), and the fauna was dominated by the Zeugmatolepadidae.

There are only four certain records of Berriasian-Barremian cirripedes, worldwide.

1. Zeugmatolepas hausmanni (Koch and Dunker, 1837) was described from the Lower Cretaceous (Hauterivian) of the Hannover district, northern Germany, based on loose valves.

2. Loriolepas decora (Harbort, 1905), from the Lower Valanginian of Musingen, northern Germany. Complete individuals and valves This is a basal calcareous-shelled form (Gale 2015).

3. Eolepas fimbriata (Withers, 1912) from the Lower Berriasian of the Czech Republic (Koci et al. 2014). This is the last occurrence of this phosphateshelled genus which appeared in the Triassic (Gale and Schweigert 2015). 4. Etcheslaepas borealis (Collins, 1990), in Århus 1990, from the Berriasian of the Barent Sea, borehole 7425/9-U-1.

So where were the cirripedes during the first 20 million years of the Cretaceous? I asked Dr Manfred Jaeger if he know of material, and he told me that they were locally common fossils in the Hauterivian clays of the 
Hannover district, and sent me numerous specimens, which proved to be of great interest. A visit to Hannover provided some additional material from an Upper Hauterivian section, an actively working claypit, Resse, which yielded a single species. Overall, the fauna proved to be unexpectedly diverse, and includes seven species, incorporated into four genera. This material thus goes some way towards filling in the gap in the fossil record.

\section{Localities and Stratigraphy}

The basinal Lower Cretaceous in the Hannover district comprises an expanded succession dominated by fossiliferous marine clays. Formerly well exposed in numerous brick pits, there are now few available localities (Mutterlose et al. 1998; Figs 1,2). However, the available material represents a significant segment of the Hauterivian of the district (Figs 1,2).

Engelbostel. A clay pit, now infilled, $5 \mathrm{~km}$ north of Hannover, exposed early Hauterivian strata of the Endemoceras amblygonium Zone (Mutterlose et al. 1998). These yielded abundant cirripede valves to Dr Manfred Jaeger, who kindly passed the material on to me.

Resse. The uppermost $3 \mathrm{~m}$ of the currently working claypit at Resse, which falls in the Upper Hauterivian Simbirskites staffi Zone (Mutterlose 2010) yielded cirripede material by surface pick and washing bulk residues. The valves are mostly broken and coated with cement.

Sarstedt (Gott). A large former working, 30km south of Hannover, formerly exposed upper Hauterivian and Barremian strata overlain unconformably by Upper Aptian (Mutterlose et al. 1998). Cirripede valves from the uppermost Hauterivian, Simbirskites discofalcatus Zone were collected by Dr Manfred Jaeger. 


\section{Systematic Palaeontology.}

Family Zeugmatolepadidae Newman, 1996

Subfamily Martillepadinae Gale, 2014a

Genus Martillepas Gale, 2014a

Type species. ?Calantica (Scillaelepas) ovalis Withers, 1928

Diagnosis. Zeugmatolepadidae which possess a reduced number of lateral plates, including two subcarinae, two rostrolatera, two carinolatera, an inframedian latus, and three accessory latera situated between the inframedian latus and rostrolatera.

Discussion. Martillepas is abundant in the Kimmeridgian of southern Germany (Gale et al. in press), and in the Tithonian Kimmeridge Clay of southern England (Gale 2014).

Martillepas hausmanni (Koch and Dunker, 1837)

Fig. 3A,B, I-R, Fig. 4A-C

1837 Pollicipes Hausmanni Koch and Dunker, p. 52, pl. 6, figs 6a-u. 1851 Pollicipes Hausmanni Koch and Dunker, Darwin, p. 53, pl.3 figs a-d. 1935 Zeugmatolepas (?) hausmanni (Koch and Dunker) Withers, p. 80, pl. 3 figs 1-6

Types. The carina figured by Dunker and Koch $(1837,3 a, b)$ was chosen by Withers (1935) as lectotype, refigured here (Fig. 4B). Hauterivian, Elligser Brink, near Delligsen, ca. $5 \mathrm{~km}$ southeast of Alfeld, Hannover. Present whereabouts unknown. 
Diagnosis. Large, robustly constructed Martillepas; terga tall, with sharp, gently curved apicobasal ridge; scuta with convex occludent margin and obtuse rostral angle; carina has flat basal margin.

Material. Numerous valves (100+) from the Lower Hauterivian Endemoceras amblygonium Zone of Engelbostel, including NHM IC 1347-1355. The species also occurs in the Hauterivian of Speeton, Yorkshire, UK (Withers 1935).

Description. Terga kite-shaped, tall, with acute basal and apical angles (Fig. $3 A, B)$. A strong, curved apicobasal ridge is present, which is inflected towards the carina. The carinal surface is narrower than the scutal-occludent surface. The valves are essentially smooth, but some (e.g. Fig. 3A) bear weak, fine, radial ridges on a depressed region of the scutal surface. The scuta (Fig. 3I-K) are robustly constructed, and triangular in outline; the occludent margin is gently convex, the rostral angle slightly obtuse and the apex acuminate and curved ventrally. A weakly defined apicobasal ridge is present, which is flattopped. On the interior of the valve (Fig. $3 \mathrm{~J}$ ) a deep tergal notch is present. The carina (Fig. $3 \mathrm{~L}, \mathrm{M}$ ) is gently incurved towards the tergum, and subcircular in cross-section. The basal margin is slightly convex, and the external sculpture consists of irregularly undulose growth lines. A probable rostrum (Fig. 3P) is kite-shaped in outline and the surfaces are angled to a central ridge. Two probable subcarinae (Fig. $3 \mathrm{Q}, \mathrm{R}$ ) are kite-shaped, with a broad central ridge, flanked by two depressed surfaces. A probable lateral plate (Fig.3O) is asymmetrically triangular, and has a smooth surface.

Remarks. The outline of the terga, which are tall, with an evenly curved single carinal margin, a short occludent margin and an acute basal angle separate this species from other Martillepas species.

Martillepas decoratus sp. nov.

Fig. 3C,D, F-H

Diagnosis. Martillepas in which the strong radial ridges bear prominent , elongated nodes where they intersect with growth increments. 
Material. Five terga from the Lower Hauterivian Endemoceras amblygonium Zone of Engelbostel, Hannover.

Types. The tergum figured (fig. 3D) is holotype (NHMUK IC 1357), the other three figured valves (Fig. 3C,F,G) are paratypes (NHMUK IC 1356, 1358, 1359).

Description. Outline of terga rhombic, with a weakly convex upper carinal margin, and slightly concave occludent margin (Fig. 3C,D,F-H). The occludent surface bears a well developed ridge for scutal articulation, and a curved apicobasal ridge is present. In some specimens (Fig. 3C,F) there is a depressed, ornate region adjacent to the scutal ridge. The sculpture consists of fine, closely spaced round-topped ridges which carry blunt nodes where these intersect with the regular growth increments (Fig. $3 \mathrm{H}$ ). In two specimens, the sculpture is confined to the depressed region of the occludent surface (Fig. 3C,F).

Remarks. The sculpture of $M$. decoratus is highly distinctive and unique. The species possibly evolved from M. hausmanni by the development of this sculpture, as the valve shapes are similar.

Martillepas auriculum sp. nov.

Fig. 5A-D, J,K

Diagnosis. Martillepas which bears a broad, finely striated auricle adjacent to the occludent margin and has an apical angle of $90^{\circ}$

Types. The broken tergum (Fig. 5B; NHMUK IC 1375) is holotype. The other figure valves are paratypes (NHMUK IC 1374, 1376 ).

Material. Ten scuta, a probable subcarina, and two lateral plates from the Upper Hauterivian S. staffi Zone of Resse, Hannover (Mutterlose 2010). A 
single tergum from the Hauterivian Speeton Clay (Bed C6) of Speeton, Yorkshire, UK. NHMUK In. 35295.

Derivation of name. Latin auriculum, an ear, in allusion to the process on the occludent margin of the tergum.

Description. Terga (Fig. 5A-C) rhombic, with apical angle of $90^{\circ}$; a strong, gently curved apicobasal ridge separates a depressed carinal surface from a higher scutal-occludent surface. A large, ear-like triangular surface extends from the apex to the apical part of the scutal margin; this bears very fine, curved ridges which run from the apex to the scutal margin. The rest of the valve surface is smooth. A possible subcarina (Fig. 5D) is triangular with a convex basal margin. Two possible lateral plates (Fig. $5 \mathrm{~J}, \mathrm{~K}$ ) are associated with the terga; one is taller than broad and bears irregular growth lines (Fig. 3J), the other asymmetrically triangular and smooth (Fig. 3K).

Remarks. The apical angle of $90^{\circ}$, and the large auricle on the occludent margin of the tergum are unique to this species. It possibly evolved from the early Hauterivian M. hausmanni by acquisition of these characters.

Genus Etcheslepas Gale, 2014a

Type species. E. durotrigensis Gale, 2014a

Included species. E. fragilis (Withers, 1928), E. borealis (Collins, 1990).

Diagnosis. Capitulum broad, with tall upper latus and rostrolatus, and numerous (50+) imbricating smaller lateral plates. Rostrum strongly convex, with four discrete surfaces.

Etcheslepas borealis (Collins, 1990) 
Fig. 6A-K

1990 Zeugmatolepas? borealis Collins, in Århus et al.,183-9, figs 9,10.

Diagnosis. Etcheslepas in which the valves bear strong apicobasal ribs and nodes where these intersect the growth increments.

Types. The scutum figured by Collins, fig. 9F (in Århus et al. 1990) is holotype. PMO 116.475 stub SK 19, Palaeontologisk Museum, Oslo, Norway. Berriasian, borehole 7425/9-U-1, Barents Sea. The other valves figured by Collins (figs 9,10) are paratypes.

Material. 55 valves from the Lower Hauterivian Endemoceras amblygonium Zone of Engelbostel, Hannover, including NHMUK IC 1363-1373 .

Description. The valves can be readily assigned to this taxon on account of the very similar sculpture which they possess, comprising regularly spaced radial ribs and grooves, and regular margin-parallel growth increments. Where these intersect the ribs, nodes are developed. Terga asymmetrically rhombic, with shorter lower carinal and occludent margins; apical angle acute (Fig. 6F$\mathrm{H})$. The strong sculpture consists of 12-16 coarse radial ridges. A weak ridge for scutal articulation is present, and the apicobasal ridge is variably developed. Scuta kite-shaped, with basal and lateral margins shorter than the occludent and tergal ones (Fig. 6A-C). The basitergal angle is acute, and a slightly curved apicobasal ridge is present, which forms a short spur at the basitergal angle. The sculpture consist of strong, rather coarse radial ribs, of which two to three form the apicobasal ridge. The carinae (Fig. 6D,E) have a semicircular cross section, and the outer surface bears eight string apicobasal ridges, with intervening grooves. Probable rostra (Fig. 6I,J) are concavoconvex, triangular, and bear apicobasal ridges. The basal margin has an apically directed, shallow V-shaped notch. A possible subcarina (Fig. 6K) is convex and triangular, with strong margin-parallel ridges. 
Remarks. E. borealis is morphologically similar to E. fragilis (Withers, 1928), and a selection of valves of this species from the Tithonian $P$. rotunda Zone of Portland, Dorset, UK are illustrated here (Fig. 6L-W). There are significant differences in valve sculpture between the two species; $E$. borealis is more strongly ribbed, especially on the terga (Fig. 6F-H), and has better developed nodes on the carina. The rostra of $E$. borealis are flatter than those of $E$. fragilis (compare fig. $6 \mathrm{I}, \mathrm{J}$ with $6 \mathrm{U}, \mathrm{V}$ ).

Occurrence. Berriasian and Valanginian, Boreal Realm. Barents Sea and northern Germany.

Genus Cretiscalpellum Withers, 1922

Type species. C. unguis (J. de C. Sowerby, 1836)

Diagnosis. Scalpellomorphs which possess a capitulum comprised of seventeen plates, including two carinolatera and a subcarina.

Included species. C. glabrum (Roemer, 1841), C. bronni (Roemer, 1841), C. striatum (Darwin, 1851), C. semiporcatum (Darwin, 1851), C. paucistriatum (Woodward, 1906), C. filosum (Withers, 1911), C. longissimum (Withers, 1911), C. imbricatum (Withers, 1910), C. C. aptiensis Withers, 1935, C. subcarinatum Withers, 1935, C. macrum Collins, 1973, C. hardeni Collins, 1973, C. vallum Collins, 1973, C. venustum Collins, 1973, C. naidini Alekseev, 2009, C. sharapovi Alekseev, 2009, C. matrioni sp. nov., C. mutterlosei sp. nov.

Remarks. Work on Cretiscalpellum since Withers' 1935 monograph includes Collin's (1973) description of new species from the Cretaceous of the USA Gulf Coast, and Alekseev's (2009) description of material from the Upper Cretaceous of Kazakhstan. Additional records of valves of species from the Albian of the UK were provided by (Collins 1974) and those from the later Cretaceous of Belgium by Jagt and Collins (1989). It is now clear that Cretiscalpellum species fall into a number of well-defined groups. 
1. Cretiscalpellum aptiensis Withers, 1935 Group. Capitulum tall and narrow, tergum with strongly curved apicobasal ridge and concave scutal margin. Scutum bears a second ridge, running from the apex to the basal margin. I had originally thought that terga of $C$. matrionisp. nov. actually belonged to Martillepas, as the shape is comparable (compare the tergum of $C$. matrioni sp. nov. in Fig. 3E with those of $M$. hausmanni, Fig. 3A,B), as also pointed out by a referee for this paper. However, valve shapes are similar to those in $C$. aptiensis, which is certainly a Cretiscalpellum. This group probably represents the most basal Cretiscalpellum, in view of the similarities with Martillepas, which is its plesiomorphic sister taxon (Gale et al. in press). Included species: C. aptiensis, C. matrioni sp. nov.

2. Cretiscalpellum unguis (J. de C. Sowerby, 1936) Group. Terga asymmetrically rhombic, with a nearly straight apicobasal ridge and straight margins. Scutum low, nearly equilaterally triangular, lacking secondary ridge. Included species: $C$. unguis, $C$. glabrum, $C$. mutterlosei sp. nov.

3. Cretiscalpellum striatum (Darwin, 1851) Group. Valves radially striate, tergum with two to three ridges sub-parallel to scutal margin. $C$. striatum, C. filosum (Withers, 1911).

Cretiscalpellum aptiensis Group

Cretiscalpellum matrioni sp. nov.

Fig. 3E, 7C,D.

Diagnosis. Smooth Cretiscalpellum with terga in which the carinal margin is strongly convex, and the carinal surface narrow. The occludent margin is as long as the scutal margin. Scutum bears two ridges, one apicobasal and a further one running to the basal margin. 
Derivation of name. After Bertrand Matrion, who has published extensive studies of the Albian of the Aube, and took the author to Le Gaty where the holotype was collected.

Material. A tergum, collected from the Middle Albian $\mathrm{H}$. bennettianus Zone of Le Gaty, Aube, France, by ASG in December 2016 is holotype. NHMUK IC 1382. A scutum, from the same locality, is paratype. Collection of B. Matrion, University of Dijon.

Description. Carinal margin of tergum strongly convex, lower and upper regions set at an obtuse angle (Fig. 3E, 6C). Apicobasal ridge sharp and strongly bowed towards the carinal margin. Occludent margin long and slightly concave, with well-developed ridge for scutal articulation on valve surface. Closely spaced, fine growth lines cover entire plate, radial sculpture lacking. Scutum subtriangular in outline, slightly taller than broad, apicobasal ridge gently curved (Fig. 7D). A stronger, slightly broader ridge runs from the apex to the basal margin. The surface bears faint, irregular radial striations close to the basal margin.

Remarks. The single well preserved tergum is very different from terga of $C$. unguis which are common at the same locality (Fig. $5 \mathrm{~N}$ ). In C. unguis, the subrhombic terga have almost straight margins, excepting the upper carinal margin which is gently convex, and the apicobasal ridge is also straight (see also Withers $1935 \mathrm{pl}$. 14), whereas in C. matrioni sp. nov. the carinal margin and apicobasal ridge are strongly convex. The scutum is relative tall, and bears an additional ridge running to the basal margin, as in $C$. aptiensis. The species is close to C. aptiensis Withers, 1935 (pl.13 fig. 1) in the shape of the tergum and scutum, but lacks the radial ribbing of that species.

Cretiscalpellum unguis Group

Cretiscalpellum mutterlosei sp. nov. 
Fig. 5,M,O.

Diagnosis. Cretiscalpellum in which the valve surfaces bear fine grooves radiating from the apices. Inframediian latus short and tall.

Derivation of name. After Professor Joerg Mutterlose of Hannover, whose work on the Lower Cretaceous has described the stratigraphy and palaeoenvironments of the Hannover region.

Types. The figured tergum (Fig. 50; NHMUK IC 1380) is holotype, the inframedian latus is paratype (Fig. 5M; NHMUK IC 1381).

Material. Two valves, a tergum and an inframedian latus, from the uppermost Hauterivian Simberskites discofalcatus Zone of Gott, Sarstedt, Hannover.

Description. The tergum (Fig. 5O) is asymmetrically rhombic, and taller than broad. A sharply defined, very gently curved, apicobasal ridge divides the carinal part of the surface from the slightly raised scutal region. The lower carinal margin is longer than the upper, and the apicobasal angle is acute. A rounded fold for scutal articulation broadens proximally along the length of the occludent margin. The surface of the scutal half of the valve bears about ten fine grooves which radiate from the apex of the valve. The carinal surface bears only rather prominent growth lines. A single plate can be identified as a inframedian latus (Fig. 5M) from the concavo-convex, asymmetrical form and the presence of a strong oblique ridge separating two surfaces. It also bears fine grooves radiating from the apex.

Remarks. C. mutterlosei is closest to $C$. unguis from the Albian of the AngloParis Basin (Fig. $5 \mathrm{~N}$ ) in the shape of the tergum, but differs in the sculpture of fine grooves on the surface. The inframedian latus is proportionately taller than that of $C$. unguis (compare Fig. 5 L, M here, also Withers $1935 \mathrm{pl} 14$ figs 8 and $9 a$ ) and also bears fine, radiating grooves like those on the tergum.

This is the oldest Cretiscalpellum known, predating C. aptiensis Withers, 1935 from the Late Aptian of the UK by about 13 myr. 
Family Scalpellidae Pilsbry, 1907

Diagnosis. Scalpellomorphs that possess a maximum of 14 plates (carina, rostrum, paired scuta, terga, upper latera, carinolatera, rostrolatera, and inframedian latera), rarely 13 , by secondary loss of the rostrum.

Remarks. Although living Scalpellidae, and fossil forms known from articulated material have a very distinctive and consistent plate number and arrangement, this cannot always be confirmed in species known from isolated valves, unless a full complement of valves has been obtained. The problem is particularly acute in basal scalpellids, which must at some stage have lost the subcarina and second carinolatera (Gale 2015, Gale et. al. 2019). However, the morphology of the carina, terga and scuta of scalpellids are quite distinctive (Withers 1935).

Genus Jaegerscalpellum nov.

Diagnosis. Scalpellids characterized by a discrete, weakly ribbed triangular region on the tergum, and a carina with a smooth, low tectum.

Remarks. Jaegerscalpellum form a small group of distinctive Lower Cretaceous scalpellid species, characterized especially by the flat, smooth tectum of the carina and a weakly sculptured triangular region on the terga. The earliest species, J. elegans sp. nov is only known from the Hauterivian of Engelbostel. J. comptum (Withers, 1910) from the Aptian of the UK, and J. politum (Darwin, 1851) from the Albian of the UK and France. The three successive species perhaps represent an evolutionary lineage.

Jaegerscalpellum elegans sp. nov.

Fig. 8A,E,J, O,P; Fig. 9A-D, F-J

Diagnosis. Jaegeroscalpellum in which the carinal and scutal surfaces of the terga bear evenly spaced, strong apicobasal ribs; carina thin, with narrow 
parietes.

Material. 35 valves from the Lower Hauterivian Endemoceras amblygonium Zone of Engelbostel, Hannover.

Types. The tergum figured here (Fig. 8A, 9A) is holotype (NHMUK IC 1383). The other figured valves are paratypes (NHMUK IC 1384-1392).

Description. Terga (Fig. 8A-C) asymmetrically rhombic, almost a parallelogram in outline; lower carinal and occludent margins shorter than upper carinal and scutal margins. Approximately twice as tall as broad, with acute apical and basal angles. Ridge subparallel to occludent margin weak, but forms short rounded prominence on uppermost scutal margin. Apicobasal ridge variably developed, strong and gently curved towards the carinal side (Fig. 8A, B) on some, weak in others (Fig. 8C). A smooth or very weakly ribbed triangular zone extends from the apicobasal ridge across half of the scutal-occlusal surface, demarcated by a second ridge running to the lower third of the scutal margin. Ribbing variable on the rest of the tergum; strong radial ribs are present on the carinal surface of the holotype (Fig. 8A), and all valves possess strong radial ribbing running from the apex to the upper two thirds of the scutal margin. Scuta (Fig. 8D, J) triangular in outline, with a gently convex occludent margin, and lack an apicobasal ridge. A depressed region adjacent to the occludent margin bears variably developed radial ribs, which are also present in a small region adjacent to the tergal margin. Intersection of the growth increments and radial ribs produces a cancellate sculpture in these regions. The rostral angle is close to $90^{\circ}$. Carinae (Fig. 8FI) gently curved in lateral aspect, thin, with low, flat parietal surfaces, tapering strongly adapically. Basal margin V-shaped, angled at approximately $120^{\circ}$; tectum flat, with weak ridges towards the lateral margins. Two lateral plates include a probable upper latus (Fig. 7J) which is equilaterally triangular in outline and weakly ribbed, and an inframedian latus (Fig. 7O, P). The inframedian latus is triangular, broader than tall, and bears strong radial ribbing. Rostrum unknown. 
Remarks. J. elegans gen. et sp. nov. is closely comparable in the morphology of the terga, scuta and carinae with the later species J. comptum and $\mathrm{J}$. politum (see below). It differs from these in the stronger ribbing on the terga. The scuta are comparable in shape to those of $J$. politum (see fig. 7E,F) but differ in the presence of radial ribs and cancellate sculpture. The carinae differ from those of J. politum in their flat form, and very shallow parietes. J. elegans gen. et sp. nov. is the oldest known member of the Scalpellidae, and extends the history of the family back by approximately $8 \mathrm{myr}$.

Jaegerscalpellum comptum (Withers, 1910)

Fig. 7B,C, 9B,D

1910 Scalpellum comptum Withers, p. 153, text-fig. 5. 1935. Scalpellum (Arcoscalpellum) comptum, Withers p. 202, pl. 23 figs 7,8 1946 Arcoscalpellum comptum Withers, p. 552, pl. 2 figs 1,2 non1965 Arcoscalpellum comptum Withers, Collins pp 629-633, pl. 90 figs 111,18

Diagnosis. Jageroscalpellum in which there is a smooth or weakly ribbed sulcus on the tergum between the triangular central region and the occludent ridge.

Remarks. The Aptian material here referred to J. comptum includes four valves, two from the Lower Aptian deshayesi Zone, Crackers Member of the Isle of Wight (NHMUK I. 21512 carina, I. XXXX tergum), and two terga from an unknown horizon in the Lower Greensand Group of Sevenoaks, Kent (In. 13403, holotype; I. 13404, paratype), figured by Withers $(1910,1935)$. The material is all refigured here. There appear to be consistent differences between this Lower Aptian species, and the form common the Middle and Upper Albian figured by Collins (1965) as A. comptum, here referred to $J$. politum (Darwin, 1851). Most importantly, there is a marked sulcus in $J$. comptum between the triangular, relatively smooth region on the central part of the tergum and the occludent ridge (Fig. 7B,C; Fig. 9B), which is lacking in J. politum (Fig. 7D, fig. 9C). Secondly, the ridge adjacent to the occludent 
margin is marked in J. comptum, but absent in J. politum. Although minor, these differences are consistent.

Jaegerscalpellum politum (Darwin, 1851)

Fig. 8D, F-H, L,M; Fig. 9E; Fig. 10A,C

1851 Scalpellum politum Darwin, p.54, pl. 3 figs 4a,b

1935 Scalpellum (Arcoscalpellum) politum Darwin, Withers p.263, pl 23 figs $2 \mathrm{a}, \mathrm{b}$

1965 Arcoscalpellum comptum Withers, Collins pp 629-633, pl. 90 figs 1-11, 18

Diagnosis. Jaegerscalpellum which lack a sulcus between the central smooth triangular region of the tergum, and in which an occludent ridge is absent.

Material. Two scuta, one tergum, a carina and a carinolatus (NHMUK IC 1384, 1393-1396) from the Upper Albian D. cristatum Subzone of Folkestone, Kent.

Remarks. Scalpellum politum Darwin, 1851 (pl.3 figs 4a,b) was based on a well preserved scutum in the collection of Mr. J. Bowerbank, probably from the Gault Clay of Folkestone, Kent, UK (reproduced here, Fig. 10A). It was characterized by the ridged occludent margin (Withers 1935). However, the unique specimen was lost, and no further material was collected subsequently. Material picked from a residue of Bed VIIli (Dipoloceras cristatum Zone) included numerous terga (Fig. 8D) belonging to a species referred by Collins (1965) to Arcoscalpellum comptum (Withers, 1910), associated with several scuta bearing an occludent ridge, exactly like that in Darwin's 1851 figure of S. politum (Fig. 8G,H). It therefore appears that the Albian Gault species should correctly be referred to as Jaegeroscalpellum politum (Darwin, 1851). The material from the Aptian Lower Greensand is morphologically distinct, and is referred to as $\mathrm{J}$. comptum (see above). 
Diagnosis. Thoracicans plesiomorphically characterized by possession of a single, tall, lateral plate, the upper latus, on each side of the capitulum, independently and secondarily lost in verrucomorphs and balanomorphs. A distinctive valve sculpture consisting of evenly spaced, ridged terraces is retained in the verrucomorph lineage (Gale 2014) but lost in balanomorphs.

Genus Pedupycnolepas Gale, 2014b

Diagnosis. Basal Unilatera which possess an elongated peduncle.

Type species. Pycnolepas articulata Collins, 1980, original designation of Gale 2014b.

Remarks. Pedupycnolepas was established on the basis of the unique holotype of Pycnolepas articulata (a cluster of specimens) from the lower Aptian of Alexander Island, Antarctica (Gale 2014b). This has a well developed peduncle (Gale 2014b, Fig. 1B). The sculpture of the terga is distinctive, comprising rather widely spaced ridges parallel to the lower carinal margin on the carinal surface of the valves. An isolated, very well preserved tergum from Engelbostel displays similar tergal sculpture and shape, and a single rostrum from the same locality is also referred to this genus.

P. pulcher sp. nov.

Fig. 11B, F

Diagnosis. Pedupycnolepas in which a broad apicobasal ridge bears apically imbricating flanges where the ridge intersects with growth increments. Terraced growth increments on carinal surface are closely spaced. Rostrum low, concavo-convex, equilaterally triangular.

Derivation of name. Pulcher, latin, meaning beautiful, with reference to the complex sculpture of the tergum. 
Material. A single well preserved tergum and a rostrum from The Lower Hauterivian Endemoceras amblygonium Zone, Engelbostel, Hannover.

Types. NHMUK IC 1397, paratype NHMUK IC 1398.

Description. The tergum (Fig. 11B) is nearly symmetrically rhombic, but for the scutal margin being slightly longer than the occludent margin. The height of the valve is twice that of the breadth, and a strong apicobasal ridge runs from the apex to the tergal angle. This ridge is gently bowed towards the carinal side and is made up of apically imbricating, flange-like nodes, each of which has a terminal swelling. A ridge for tergal articulation is present adjacent to the occludent margin. The valve sculpture is complex and variable across the valve, and is dominated by evenly spaced, terraced, growth increments, each approximately 50 microns apart. Simple ridges cover the carinal surface of the valve, but on the scutal/occludent surface, these ridges bear evenly spaced (50 microns) tooth-like structures, directed towards the scutal margin. The flanges on the apicobasal ridge develop where the regularly spaced terracing crosses the ridge. The rostrum (Fig. 11F) is concavo-convex, equilaterally triangular in ventral view and has a gently curved proximal margin. The strong sculpture comprises proximally imbricating, evenly spaced ridges, which are interrupted to form poorly defined tubercles on the lateral surfaces of the plate. A rostrum of Faxoepycnolepas (Fig. 11G) is provided for comparison; it is taller, the ridges are less sharply defined, and a stronger radial sculpture is developed.

Discussion. P. pulcher sp. nov. differs from $P$. articulata in the broader, strongly nodose, apicobasal ridge and the more closely spaced, narrower, terracing on the carinal surface of the tergum.

The sculpture of $P$. pulcher sp. nov. is remarkably similar to that developed on many verrucids (Gale 2014b), and a selection of these are illustrated for comparison (Fig. 11 C,D,E,H). The main elements of this sculpture are: 
- evenly spaced, apically imbricating terraces of calcite which protrude slightly on the occludent margin of the terga, and represent regular growth increments.

- Scalloped, strongly imbricating proximal extensions of the terraces on the apicobasal ridge.

- A weak, variably developed radial sculpture, confined to the lower scutal surface of the terga.

Pedupycnolepas falls close to the base of the unilateran clade, which includes both verrucomorphs and balanomorphs (Gale 2018), and the distinctive sculpture is evidently plesiomorphic for the group. However, it is retained on the moveable scuta of all verrucids (e.g. Fig. 11H) but lost on the wall plates of derived verrucids and all balanomorphs (Gale 2014b). Etcheslepas durotrigensis Gale, 2014a, from the Tithonian Kimmeridge Clay, shows incipient development of this sculpture type (e.g. Gale 2018 Fig. 2), in the form of regularly spaced, weak terracing or ribbing, particularly on the scuta adjacent to the occludent margin. The Unilatera may have originated from a form like E. durotrigensis, which lost all lateral plates except the tall upper latus and further elaborated the sculpture.

\section{Discussion.}

The new cirripede faunas from the Hauterivian of the Hannover district provide important new information on the history of the group during the Lower Cretaceous, summarized in Fig. 12. Firstly, zeugmatolepadids of the subfamily Martillepadinae (i.e. those with apical scutal umbones) belonging to the dominantly Late Jurassic genera Martillepas and Etcheslepas extended up as common elements of the fauna into the Late Hauterivian. Secondly, the early occurrences (Hauterivian) of typically later Cretaceous genera such as Cretiscalpellum and the scalpellid Jaegerscalpellum gen nov. extend their history back by many millions of years. Also, the early Hauterivian occurrence of the unilateran genus Pedupycnolepas constrains the date of the evolution of this group, which ultimately gave rise to the balanomorphs and 
verrucomorphs (Gale 2018). Thus, the Cretaceous radiation of the thoracicalarean cirripedes was underway by the Hauterivian. It appears likely that zeugmatolepadids gave rise to all later calcareous cirripedes, although the details of the phylogeny remain obscure. However, it is likely that Martillepas gave rise to Cretiscalpellum by reduction in lateral plates (Gale et al. 2019).

\section{Conclusions.}

Cirripedes described from the Hauterivian of Germany include seven species which are placed in five genera, They include an admixture of typically upper Jurassic forms belonging to the zeugmatolepadid subfamily Martillepadinae (Martillepas hausmanni, M. decoratus sp. nov., M. auriculus sp. nov and Etcheslepas borealis), together with forms typical of the later Cretaceous, including the oldest species of Cretiscalpellum (C. mutterlosei sp. nov.) and the oldest Scalpellidae (Jaegerscalpellum gen nov., species $J$. elegans sp. nov.). Additionally, Pedupycnolepas pulcher sp. nov, is the earliest member of the Group Unilatera, which gave rise to the verrucomorphs and balanomorphs in the later Cretaceous.

\section{Acknowledgements.}

I am extremely grateful to Dr. Manfred Jaeger for giving me his cirripede material from the Hannover district, and to Professor Joerg Mutterlose and $\mathrm{Dr}$ Jochen Erbacher for hosting a visit to Hannover to look for cirripedes in 2016. I also thank the referees (John Jagt and Tomas Koci) for their valuable reviews.

\section{References}

Alekseev, A. S. 2009. Usonogie raki (Cirripedia, Thoracica) verkhnego mela Mangyshlaka. Byulleten' Moskovskogo Obshchestva Ispytatelej Prirody, Otdel Geologicheskij, 84, 23-38. 
Århus, N., Kelly, S.R.A., Collins, J.S.H., Sandy, M.R. 1990. Systematic palaeontology and biostratigraphy of two Early Cretaceous condensed sections from the Barents Sea. Polar Research 8, 165-194.

Buckeridge, J.S. 1997. Cirripedia:Thoracica: New ranges and species of Verrucomorpha from the Indian and Southwest Pacific Oceans. In: Crosnier, A. (ed.), Résultats des Campagnes MUSORSTOM, Volume 18. Mémoires du Museum nationale d'Histoire naturelle, 176, 125-149.

Collins, J.S.H. 1965. Arcoscalpellum comptum (Withers), a species of cirripede new to the Gault. Palaeontology 8, 629-633.

Collins, J.S.H. 1973. Cirripedes from the Upper Cretaceous of Alabama and Mississippi, eastern Gulf region, U.S.A. Bulletin of the British Museum (Natural History), Geology, 23 (6), 351-388.

Collins, J.S.H. 1974. Recent advances in the knowledge of Gault Cirripedia. Proceedings of the Geologists' Association 85, 377-386.

Collins, J.S.H. 1980. A new Pycnolepas (Cirripedia) from the (?)Lower Aptian of Alexander Island. Bulletin of the Antarctic Survey, 50, 21-26.

Darwin, C.R., 1851. A monograph on the sub-class Cirripedia, with figures of all the species. The Lepadidae, or pedunculated crripedes. The Ray Society, London. xii + 400 pp., 10 pls.

Gale, A.S. 2014a. New thoracican cirripedes (Crustacea) from the Jurassic and Cretaceous of the UK. Proceedings of the Geologists' Association 125, 406-418.

Gale, A.S. 2014b. Origin and phylogeny of the verrucomorph cirripedes (Crustacea; Thoracica). Journal of Systematic Palaeontology, http://dx.doi.org/10.1080/14772019.2014.954409

Gale, A.S. 2015a. Origin and phylogeny of the thoracican cirripede family Stramentidae. Journal of Systematic Palaeontology, http://dx.doi.org/10.1080/14772019.2015.1091149

Gale, A.S. 2015b. Phylogeny of the deep sea cirripede family Scalpellidae based on capitular plate morphology. Zoological Journal of the Linnean Society 176, 1-34.

Gale, A.S. 2018. Stalked barnacles (Cirripedia, Thoracica) from the Upper Jurassic (Tithonian) Kimmeridge Clay of Dorset, UK; palaeoecology 
and bearing on the evolution of living forms. Proceedings of the Geologist's Association

Gale, A.S., Schweigert, G. 2015. A new phosphatic-shelled cirripede (Crustacea, Thoracica) from the Lower Jurassic (Toarcian) of Germany - the oldest epiplanktonic barnacle. Palaeontology, doi:

10.1111/pala.12207

Gale, A.S., Schweigert, G., Keupp, H., Röper, M. 2019 in press. A thoracican cirripede (Crustacea) from the Kimmeridgian of Brunn, Germany, and its bearing on the origin of calanticid and scalpellid barnacles. Neues Jahrbuch für Geologie und Paläontologie.

Harbort, E. 1905. Die Fauna der Schaumburg-Lippe'schen Kreidemulde. Abhandlungen der Preussischen Geologischen Landesanstalt, 45, 1112, 12 pls

Keupp, H., Röper, M., Seilacher, A. 1999. Paläobiologische Aspekte von syn vivo-besiedelten Ammonoideen in Plattenkalk des OberKimmeridgiums von Brun in Ostbayern. Berliner geowissenschaftliche Abhandlungen E30.

Koch, F.C.L.,Dunker, W.B.R.H. 1837. Beitrage zur Kenntniss des Norddeutschen Oolithgebildes und dessen Versteinerungen. 64pp., 7pls. Braunschweig.

Kocí, T., Kocova Veselská, M., Gale, A.S., Jagt, J.W.M., Skupien, P. 2015. Late Jurassic-Early Cretaceous stalked barnacles (Cirripedia, genus Eolepas Withers, 1928) from Štramberk, Moravia (Czech Republic). Neues Jahrbuch für Geologie und Paläontologie Abhandlungen 275(2), 233-247.

Mutterlose, J., Bornemann, A., Rauer, S., Spaeth, C., Wood, C.J. 1998. Key localities of the northwest European Cretaceous. Bochumer Geologische und Geotechnische Arbeiten 48, 1-231, 169 figs. Bochum. Mutterlose, J. 2010. Die Tongrube Resse nördlich von Hannover (Abb. 1,2,3). Arbeitskreis Paläontologie Hannover 38, 4-8.

Newman, W.A. 1996. Cirripedia; suborders Thoracica and Acrothoracica. In: Forest, J. (ed.). Traité de Zoologie. Anatomie, systématique, biologie, 7(2), 453-540. Masson, Paris. 
Pilsbry, H.A. 1907. The barnacles (Cirripedia) contained in the collections of the U.S. National Museum. Bulletin of the United States National Museum 60, 1-122,11 pls.

Sowerby, J. de C. 1836. Descriptive notes respecting shells figured in plates 11-22 (pp. 335-348). Appendix A to Fitton, W.H. Observations on some of the Strata between the Chalk and the Oxford Oolite in the SouthEast of England. Transactions of the Geological Society of London, (2) 4, 103-389, pls 11-23.

Withers, T.H. 1910. The Cretaceous cirripede Pollicipes laevis, J. de C. Sowerby. Geological Magazine dec. 5, 7, 495-501, figs. 1-8.

Withers, T.H. 1912. Two new species of cirripede from the Tithonian of Stramberg, Moravia. Geological Magazine, dec. 5, 9, 505-508, pl. 23. Withers, T.H. 1922. The morphology of some Cretaceous cirripedes. Annals and Magazine of Natural History, 9(9), 368-379, pl. 5.

Withers, T.H. 1928. British Museum (Natural History). Catalogue of fossil Cirripedia in the Department of Geology. Vol. 1. Triassic and Jurassic, xii + 154 pp., 12 pls. Trustees of the British Museum (Natural History), London.

Withers, T.H. 1935. British Museum (Natural History). Catalogue of fossil Cirripedia in the Department of Geology. Vol. 2. Cretaceous, xiii +534 pp., 50 pls. Trustees of the British Museum (Natural History), London.

Withers, T.H. 1946. New Cretaceous Cirripedes and Crab. Annals and Magazine of Natural History (2) 12, 552-561, pl. 2.

Withers, T.H. 1953. British Museum (Natural History). Catalogue of fossil Cirripedia in the Department of Geology. Vol. 3. Tertiary, xv + 396 pp., 64 pls. Trustees of the British Museum (Natural History), London. 
Figure captions.

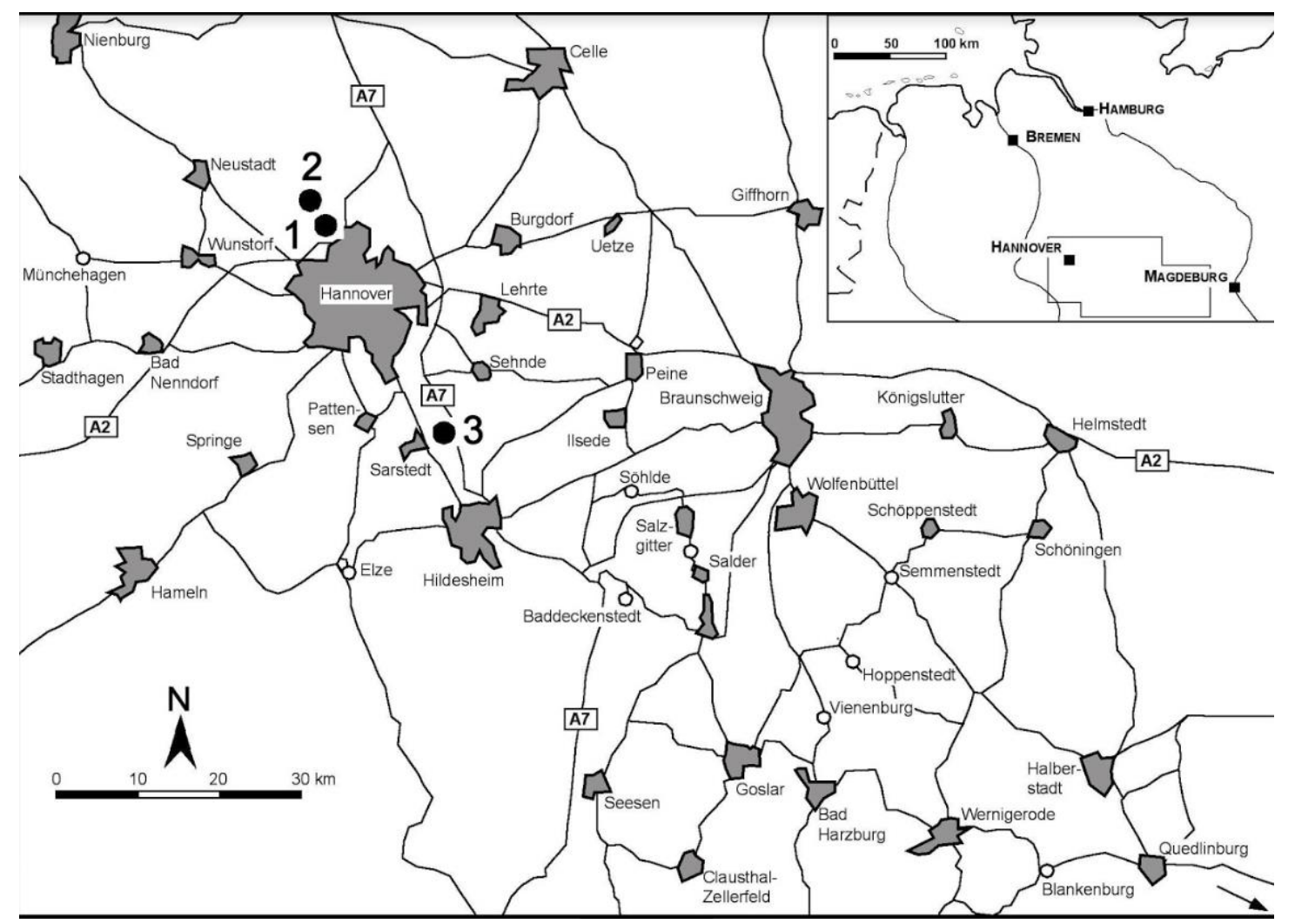

Fig. 1. Map of the Hannover district, to show the locations of Lower Cretaceous exposures at Resse (1), Engelbostel (2) and Gott (3). After Mutterlose et al. 1999 Fig. 2. 


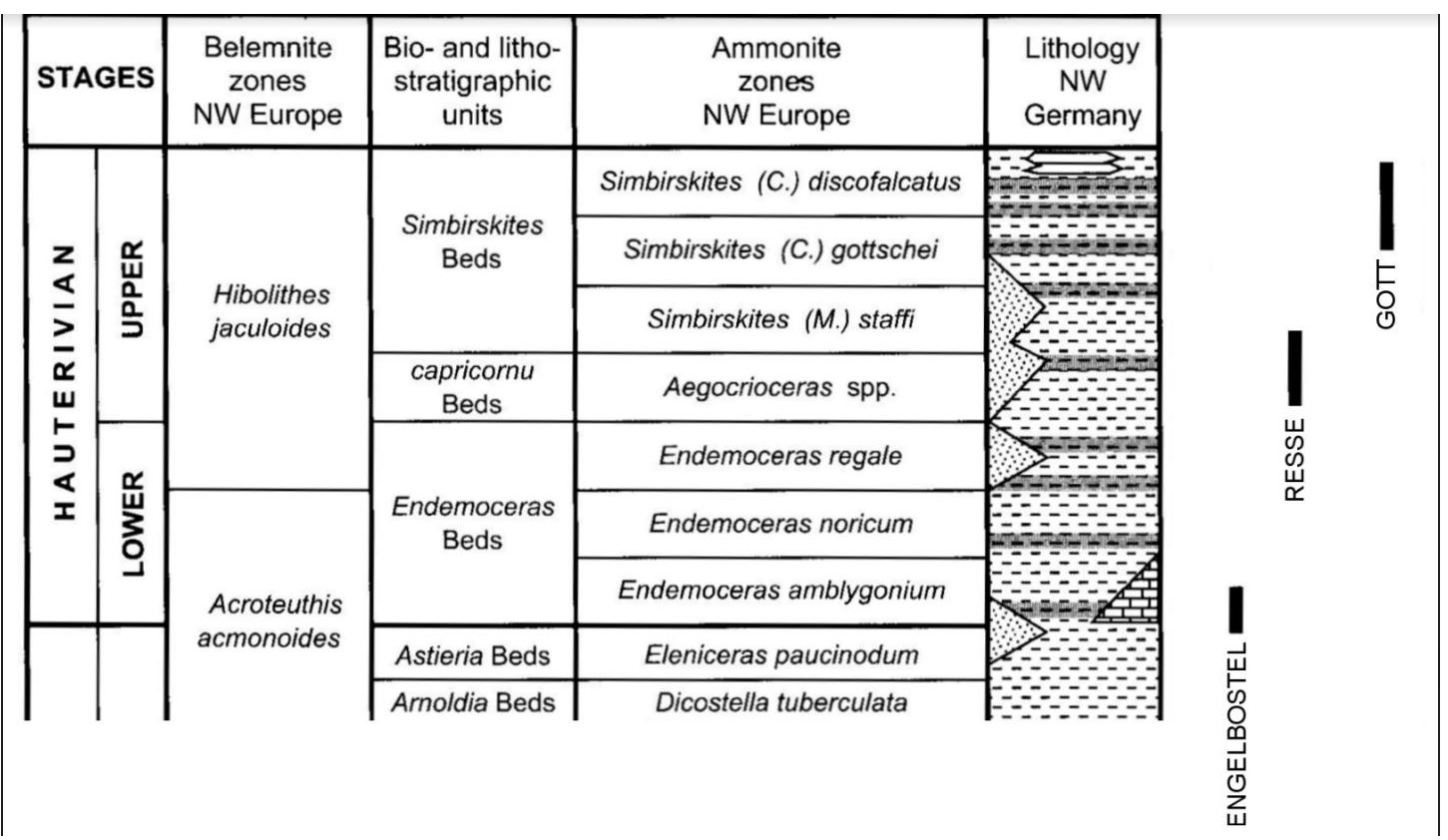

Fig. 2. Lithology and biostratigraphy of the Hauterivian of NW Germany, to show the levels exposed in the claypits at Engelbostel, Resse and Gott. After Mutterlose et al. 1999, Fig. 4. 


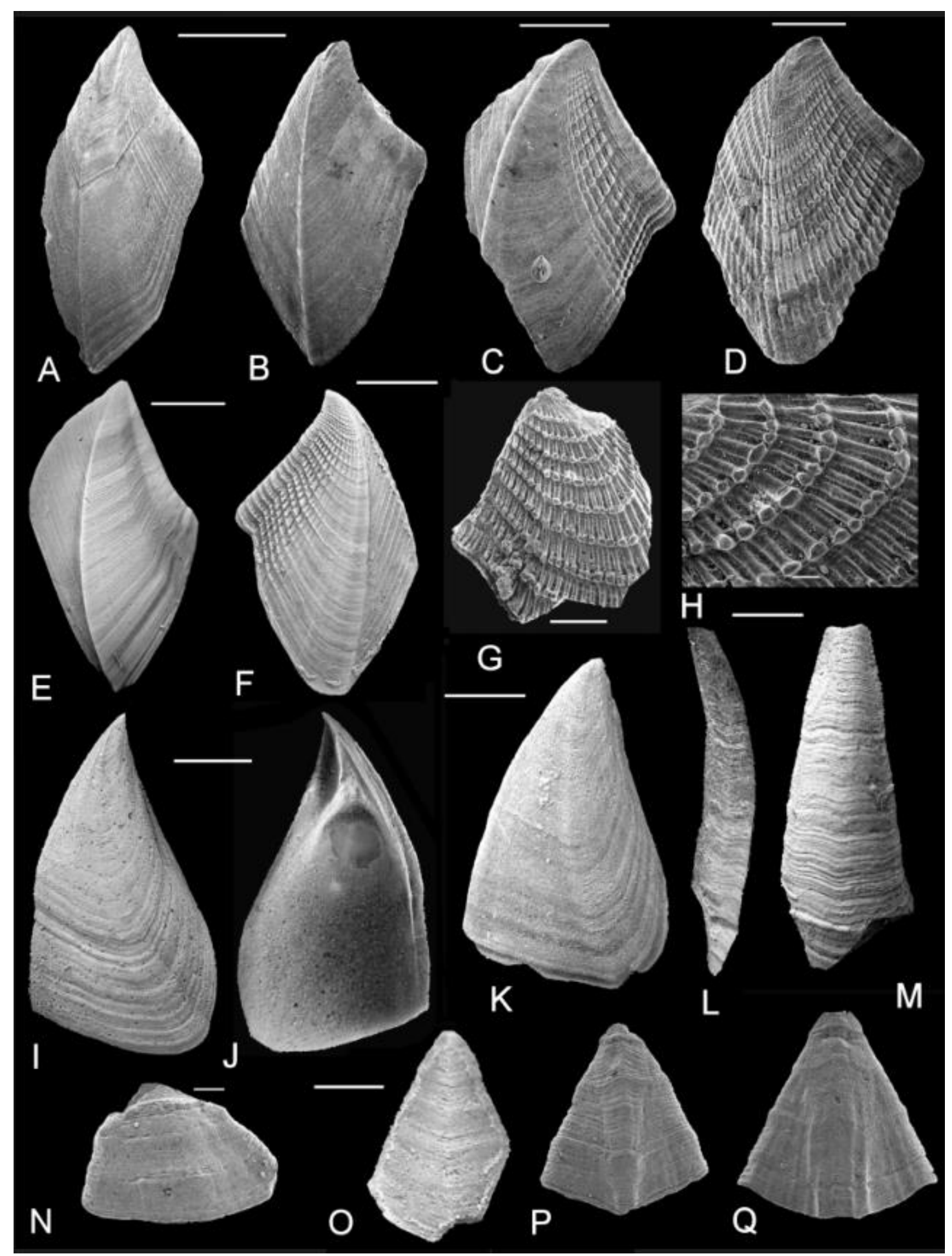

Fig. 3.A,B,I-R, Martillepas hausmanni (Koch and Dunker, 1837). A,B, terga, NHMUK IC 1347, 1348. I,J,K, scuta, in external (I,K) and (J) internal views, NHMUK IC 1348, 1349. L,M, carina, in lateral (L) and dorsal (M) aspects, NHMUK IC 1351. N, lateral plate, external view. NHMUK IC 1352. O, probable rostrum in dorsal view, NHMUK IC 1353. P,Q, possible subcarinae, dorsal view, NHMUK IC 1354, 1355. C,D,F,G,H, Martillepas decoratus sp. 
nov. Terga in external lateral view. C,F, forms with relative weak sculpture, NHMUK IC 1356, 1358, paratypes. D, G, H, strongly ornate forms, D is holotype, NHMUK IC 1357, G a paratype, NHMUK IC 1359. H, enlargement of $G$, to show structure of ribbing. All from the Lower Hauterivian Endemoceras amblygonium Zone, Engelbostel, near Hannover. E, Cretiscalpellum matrioni sp. nov. holotype tergum, NHMUK IC 1382. Middle Albian, Hoplites bennettianus Zone, Le Gaty, Aube, France.

Scale bars. E, 4mm. F-M, P, 2mm. A-C, 1mm. D,G, 0.5mm. O,Q,R, 0.2mm. $\mathrm{H}, 0.1 \mathrm{~mm}$.

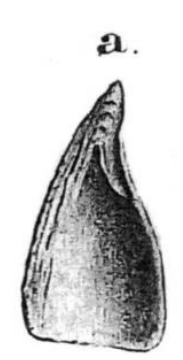

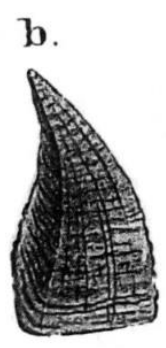

A

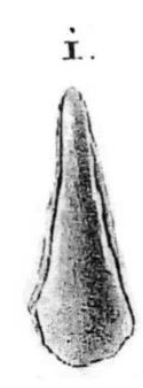

6.

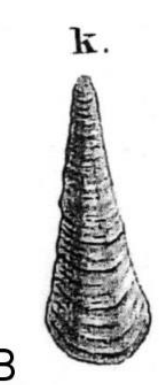

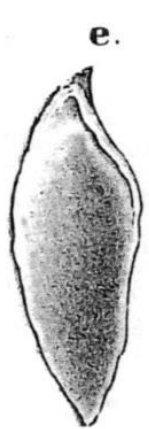

C

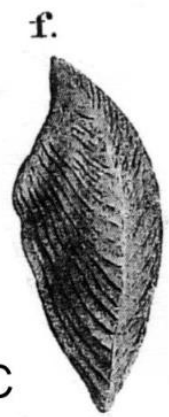

Fig. 4. Reproduction of original figure of Pollicipes Hausmanni Koch and Dunker, 1836, to show original material of scutum (A), carina $(B)$ and tergum (C). The carina was selected as lectotype by Withers (1935). Hauterivian, Elligser Brinkes, Hannover. Whereabouts unknown. 


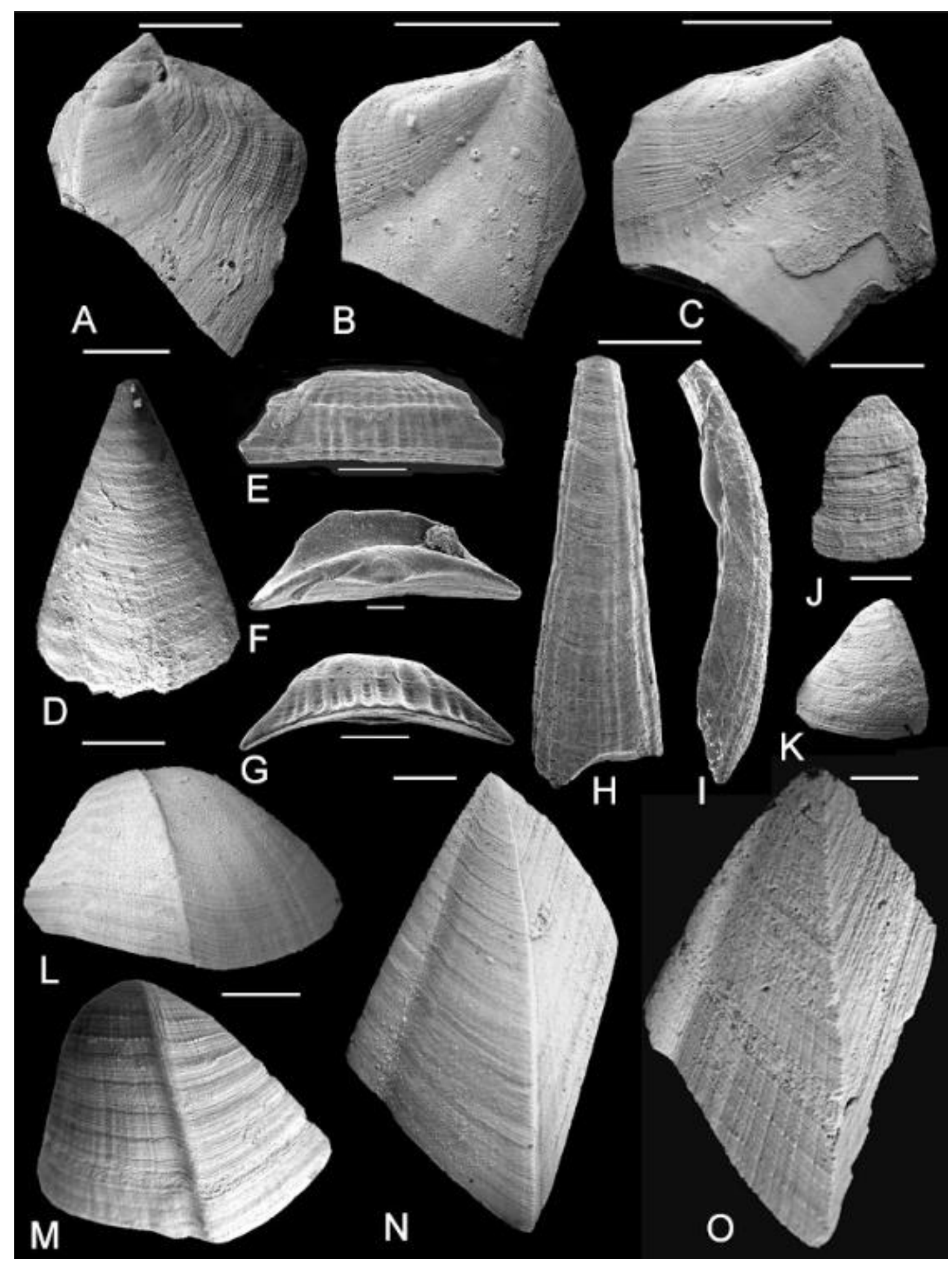

Fig. 5. A-D,J,K, Martillepas auriculus sp. nov. A-C, fragmentary terga, external view; B, holotype, NHMUK IC 1375, A and C paratypes, IC 1374, 1376. D, probable subcarina, dorsal view, NHMUK IC 1377. J,K, lateral plates, NHMUK IC 1378, 1379. Upper Hauterivian, Simbirskites staffi Zone, Resse, near Hannover. E-G, peduncular plates, of unknown affinities NHMUK IC 13601362. Lower Hauterivian Endemoceras amblygonium Zone, Engelbostel, 
near Hannover. H,I, carina, of unknown affinity. NHMUK IC 1362A. M,O, Cretiscalpellum mutterlosei sp. nov. M, paratype inframedian latus, external view, NHMUK IC 1381. O, holotype tergum, NHMUK IC 1380. Upper Hauterivian. Simbirskites discofalcatus Zone, Gott, near Hannover. L,N, Cretiscalpellum unguis (J. de C. Sowerby, 1836). L, inframedian latus in external view, N, tergum in external view. Middle Albian, Hoplites bennettianus Zone, Le Gaty, Aube, France. B. Matrion collection, University of Dijon.

Scale bars. A-C, 5mm. H-K, L-O 2mm. e-G, 0.5mm. 


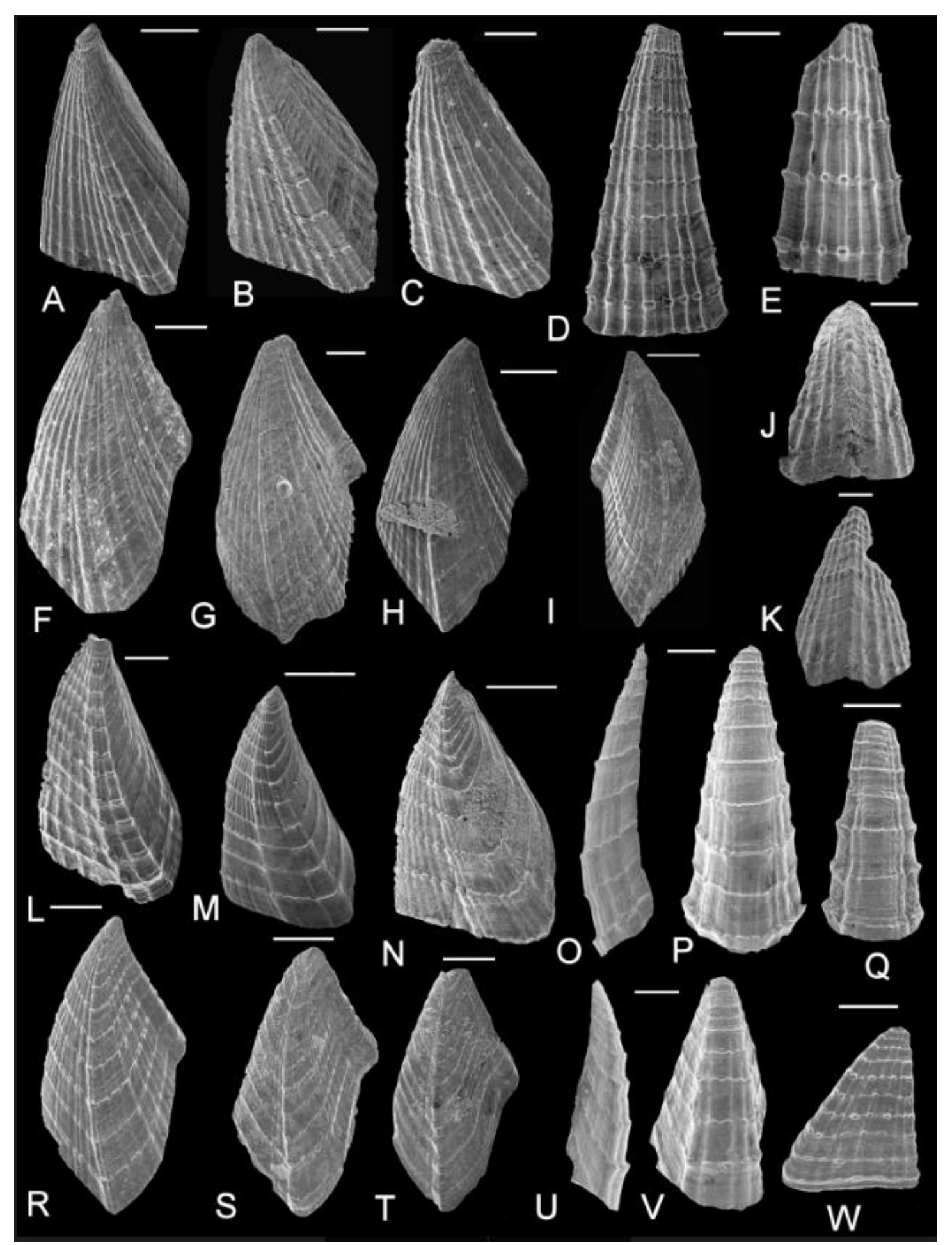

Fig. 6. A-K, Etchelepas borealis (Collins, 1990). A-C, scuta in external view, A, NHMUK IC 1363. B,C, NHMUK IC 1364, 1365. D,E, carinae in dorsal view, NHMUK IC 1366, 1367. F-I, external views of terga, NHMUK IC 1368-1371. J,K, probable subcarinae, NHMUK IC 1372, 1373. Lower Hauterivian Endemoceras amblygonium Zone, Engelbostel, near Hannover. L-W, Etcheslepas fragilis (Withers, 1928). L-N, scuta; L, original of Gale 2014a Fig. 5d, NHMUK IC 1093. N, original of Gale 2014a Fig. 4b, NHMUK IC 1091. M, 
scutum, NHMUK IC 1366A. O-P, carina, original of Gale 2014a Fig. 6, J,K, NHMUK IC 1099. Q, subcarina, original of Gale 2014a, Fig. 6p, NHMUK 1100. R-T, terga. R, NHMUK IC 1366B. S, original of Gale 2014a, Fig. 6a, NHMUK IC 1094. T, original of Gale 2014a, Fig. 6b, NHMUK IC 1095. U,V, rostrum, original of Gale 2014a, Fig. 6f,g, NHMUK IC 1097. W, possible upper latus, original of Gale 2014a, Fig. 6h, NHMUK IC 1098. All from the upper Pavlovia pallasioides Zone, Tithonian, Portland, Dorset, UK.

Scale bars. A,R, 1mm. B-E, G,H, L-P, S,T, 0.5mm. I-J, Q, U-W, 0.2mm.

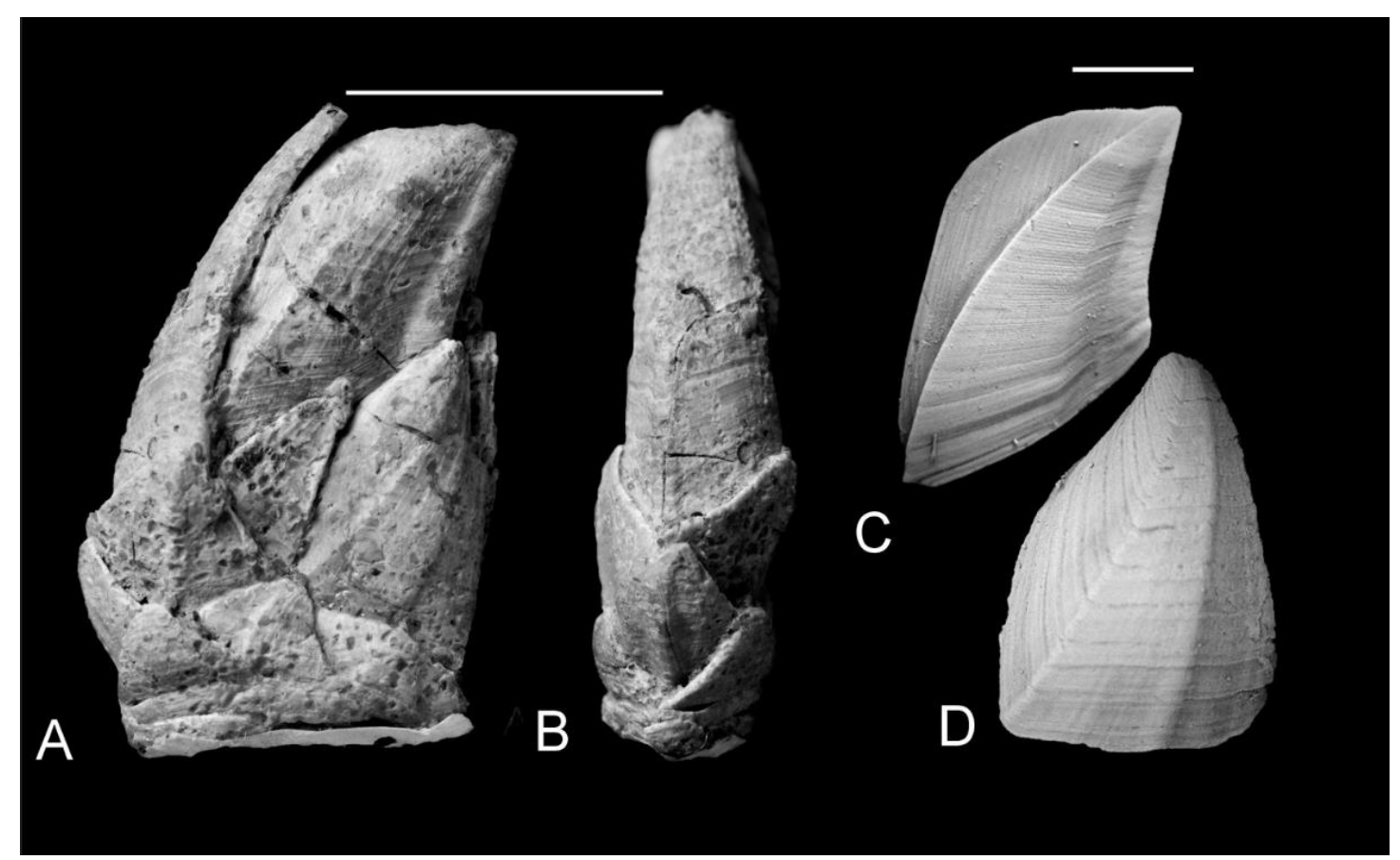

Fig. 7. A,B, Cretiscalpellum aptiensis Withers, 1935. Lateral (A) and carinal (B) aspect of holotype, BGS 49533. Late Aptian, Bargate Stone, Lydling, near Guildford, Surrey, UK. C,D, Cretiscalpellum matrioni sp. nov. C, holotype tergum, external view. NHMUK IC 1380. D, paratype scutum, external view. B. Matrion coll., University of Dijon. Middle Albian, Hoplites bennettianus Zone, Le Gaty, Aube, France.

Scale bars. A,B, 10mm; C,D, 4mm. 


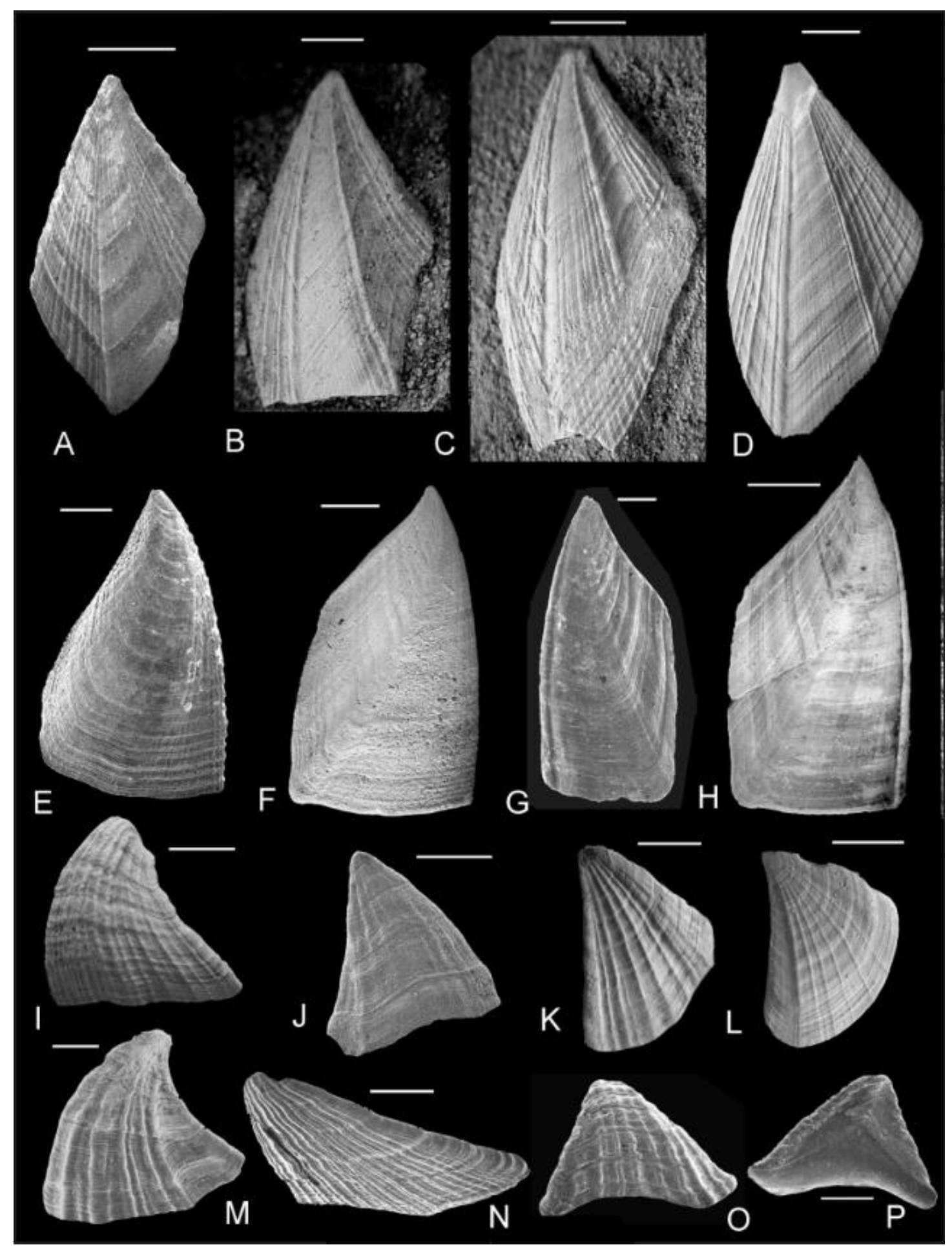

Fig. 8 A, E,J,O,P, Jaegerscalpellum elegans sp. nov. A, holotype tergum, NHMUK IC 1383. E, scutum, paratype, NHMUK IC 1384. J, possible upper latus, NHMUK IC 1385. O,P, inframedian latus, NHMUK IC 1386. Lower Hauterivian Endemoceras amblygonium Zone, Engelbostel, near Hannover. B,C, Jaegerscalpellum comptum (Withers, 1910). Terga, originals of Withers 1935 pl. 23 figs 7,8. B, paratype, I. 13404. C, holotype, I. 13403. Lower Greensand, Aptian (probably Lower), Sevenoaks, Kent, UK. D,F-H, M,L, 
Jaegerscalpellum politum (Darwin, 1851). D, tergum, NHMUK IC 1393. F-H, scuta. F, original of Collins 1965, pl. 90 fig. 10, NHMUK In 64257. G,H, NHMUK IC 1394, 1395. Note narrow ridge parallel with occludent margin. M, carinolatus, NHMUK IC 1396. L, upper latus, original of Collins 1965 pl. 90 fig. 8, NHMUK In 64255. I, N, K, Arcuatoscalpellum arcuatum (Darwin, 1851). I, carinolatus, NHMUK In. 61368, original of Collins 1974 pl. 11 fig. 10. K, upper latus, original of Collins 1965, pl. 90 fig. 9, NHMUK In 64256. N, rostrolatus, original of Gale, 2015a, fig. 4M. NHMUK IC 1221. D,G,H,M,N, Upper Albian, Dipoloceras cristatum Zone, Bed VIli, Folkestone, Kent, UK. I,K,L, Upper Albian, Mortoniceras pricei Zone, $H$. orbignyi Subzone, Paddlesworth, Kent, UK.

Scale bars. A-D,F,H,I, 1mm. E,G,J-L, N-P, 0.5mm. M, 0.2mm.

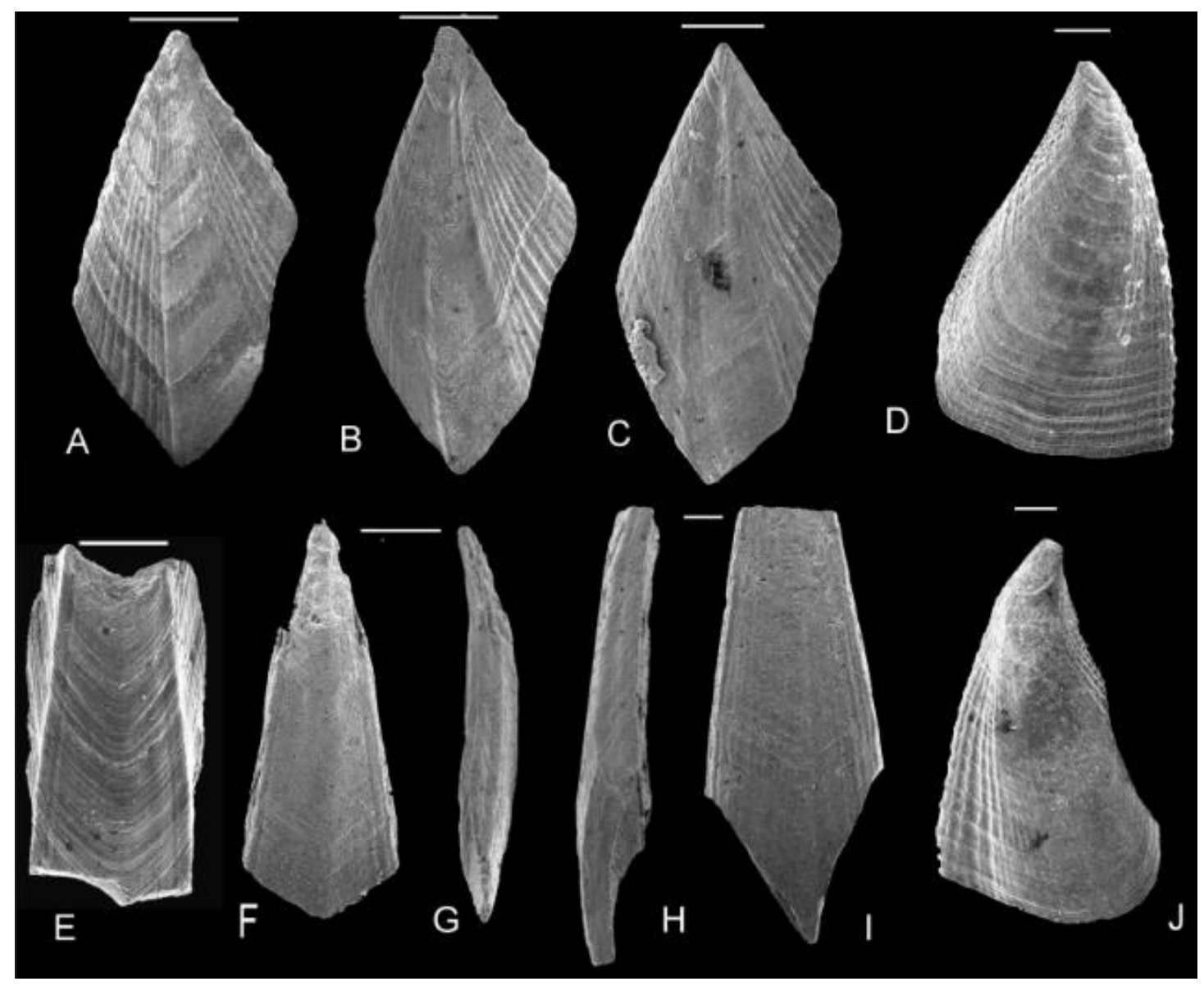

Fig. 9. A-D, F-J,Jaegerscalpellum elegans sp. nov. A-C, terga. A, holotype, NHMUK IC 1383. B,C, paratypes, NHMUK IC 1387, 1388. D,J, scuta in external view. NHMUK IC 1389, 1392. F-I, carinae, in dorsal (F,I) and lateral views $(G, H)$, paratypes, NHMUK IC 1390, 1391. Lower Hauterivian 
Endemoceras amblygonium Zone, Engelbostel, near Hannover. E, Jaegerscalpellum politum (Darwin, 1851), carina, in dorsal view. NHMUK IC 1384. Upper Albian, Dipoloceras cristatum Zone, Bed VIli, Folkestone, Kent, UK.

Scale bars. A, $1 \mathrm{~mm}$. B-J, $0.5 \mathrm{~mm}$.

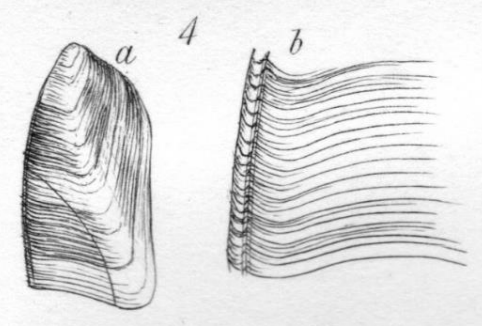

A
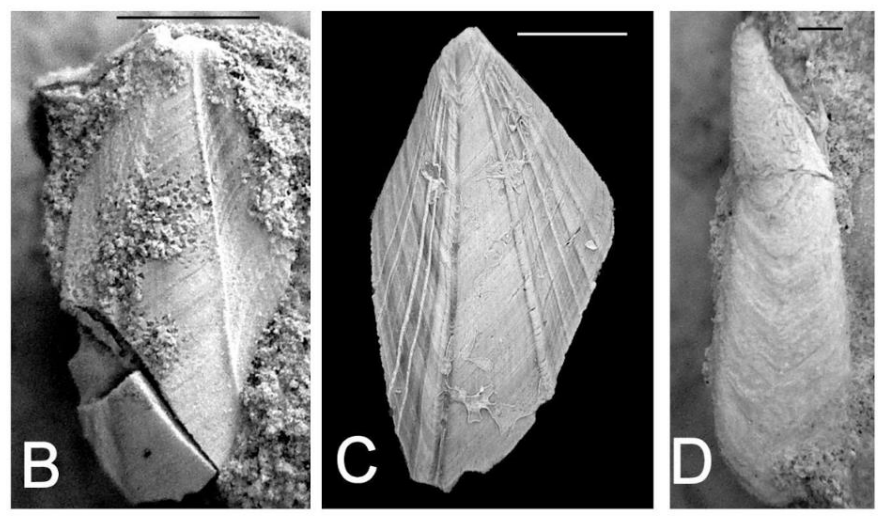

Fig. 10. A, original figure Pollicipes politum Darwin, 1851, pl. 3 fig. 4.

Collection of Mr J. Bowerbank, presumed to be from the Gault Clay.

Specimen lost. B, D, Jaegerscalpellum comptum (Withers, 1910) NHMUK In 63507a. D, carina, in dorsal view. Original of Withers 1946, figs. 1,2. NHMUK In 63507b. Lower Aptian, Deshayesites deshayesi Zone, Crackers Member, Atherfield, Isle of Wight, UK. C, Jaegerscalpellum politum (Darwin, 1851).

Tergum. Middle Albian, Hoplites bennettianus Zone, Le Gaty, Aube, France.

B. Matrion collection.

Scale bars. $2 \mathrm{~mm}$. 


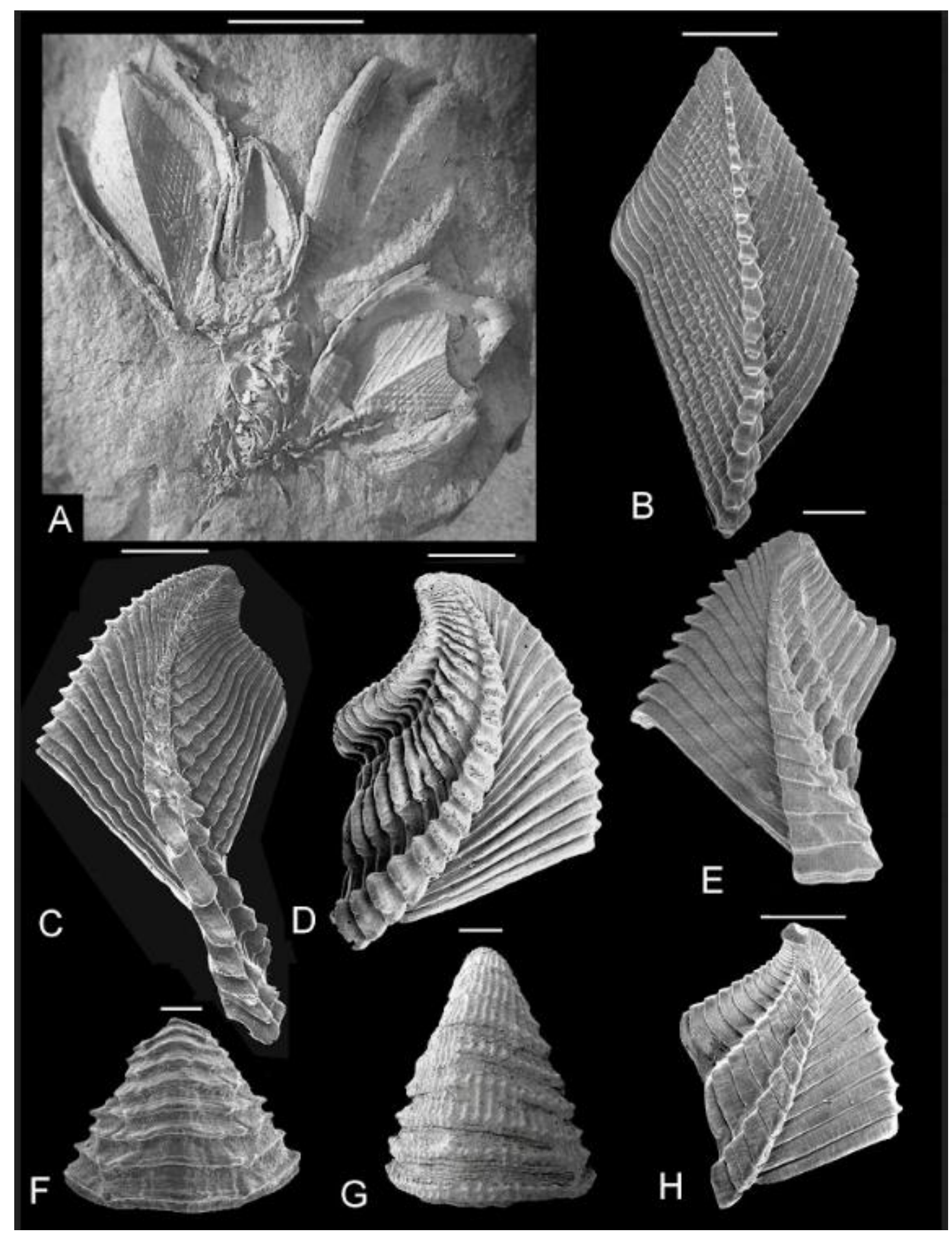

Fig. 11. A, Pedupycnolepas articulata (Collins, 1980). Fossil Bluff Formation, ?lower Aptian, Alexander Island, Antarctica; A, holotype BAS KG. 1657b and two paratypes KG 1657a, c. B, F, Pedupycnolepas pulcher sp. nov. B, holotype tergum, NHMUK IC 1397. F, paratype rostrum, NHMUK IC 1398. Lower Hauterivian Endemoceras amblygonium Zone, Engelbostel, near Hannover. C,D, Altiverruca jonesae Buckeridge, 1997. C, fixed tergum, D, moveable tergum. NHMUK IC 1399, 1400. H, Metaverruca sp., moveable 
tergum. NHMUK IC 1401. C,D, H, Late Pliocene, off Rodrigues Ridge, Indian Ocean. E, Eoverruca hewitti Withers, 1935. Fixed tergum. Santonian, Uintacrinus socialis Zone, Hinderclay Lane, Wattisfield, Suffolk, UK. G, Faxoelepas bruennichi (Withers 1914a), rostrum. After Gale 2014 Fig. 4C, NHMUK IC 1023. Middle Danian (Palaeocene), Faxoe, Denmark. Note the similarity of surface sculpture between the tergum of $P$. pulcher sp. nov. (B) and that of Verrucidae $(\mathrm{C}-\mathrm{E}, \mathrm{H})$. This comprises regularly spaced, proximally imbricating growth increments, which form a serrated occludent margin, and scalloped processes over the apicobasal line.

Scale bars. A, 5mm; B-D, H, 1mm; E-G, 0.5mm. 


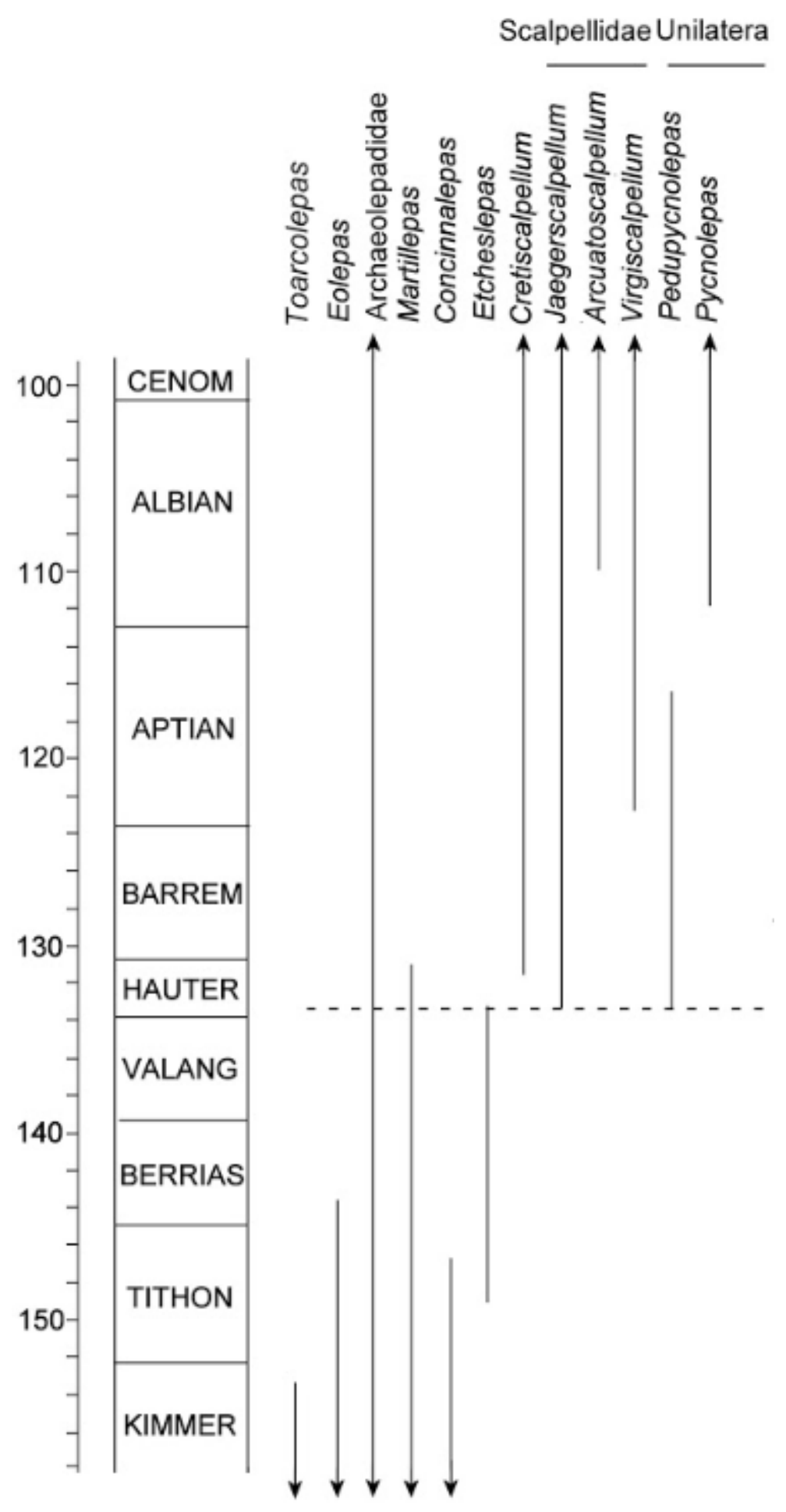

Fig. 12. Distribution of cirripedes in the Late Jurassic and Lower Cretacous. The dotted line represents the position of the Engelbostel Fauna. Note the extension of Jurassic genera into the Hauterivian, in which calanticids and scalpellids first appear. 